\title{
KNOWLEDGE ECONOMY: TRENDS IN THE WORLD AND ANALYSIS OF UKRAINE
}

\author{
Halyna Zelinska \\ Ivano-Frankivsk National Technical University of Oil and Gas, Ukraine \\ Uliana Andrusiv \\ Ivano-Frankivsk National Technical University of Oil and Gas, Ukraine \\ Liliia Simkiv \\ Ivano-Frankivsk National Technical University of Oil and Gas, Ukraine
}

\begin{abstract}
The objective of the article is to study the regional development of Ukraine through the prism of indicators that characterize the knowledge-based economy, comparing it to other countries. It has been determined that the appearance of a new economy in the world arena is dictated by time and new trends in the world. Performed study justified that in the conditions of Ukraine, economic knowledge can be a breakthrough in the country's growth. Given the ambiguity and uneven economic development of the administrative-territorial units of Ukraine, the main destabilizing factors that hinder the successful implementation of reforms have been identified. A comparative analysis of the Ukrainian economy with that of Poland has been carried out. Also, the competitive advantages of the Polish economy have been identified, where the main factors are indicated as the highly developed human potential and the existence of substantial funding toward academic research. For this reason, the critical requirements for Ukraine's development are economic knowledge based on science, modern technologies, improved educational system, and continues professional training of executive management personnel.
\end{abstract}

Keywords: Knowledge economy, globalization, human capital, Ukraine, Index of the knowledge economy.

DOI: http://dx.doi.org/10.15549/jeecar.v7i1.325

\section{INTRODUCTION}

In the market conditions, the functioning of the national economy is widely known as the term "knowledge economy" or "economics based on knowledge." The fundamental elements of the knowledge economy are scientific knowledge and education, which, in the period of intensification of competitive relations and globalization, become a determining source and one of the main factors of stimulation of both material and nonmaterial production.

Society is under the influence of radical changes associated with the gradual 
replacement of labor knowledge. The labor theory of value is transformed into the theory of "value-created knowledge" (knowledge-value).

In Ukraine, the process of institutionalization of the knowledge economy that is reflected in many forms (legislative and normative acts, forms and schemes of interactions, etc.) is variable, not permanent and not always justified, even without mentioning the motivational component. Such a situation requires the development and adoption of a well-balanced and effective strategy of the development of the knowledge economy at the state level, that is based on the peculiarities of the regions' livelihoods, a characteristic feature of which is the disproportionate development of economic growth.

\section{REVIEW OF LITERATURE}

The Japanese researcher Sakayya (1999), developed the theory of value created by knowledge. In his work "Value created by knowledge: the history of the future" he indicated that in today's economic conditions, traditional factors of production no longer determined the value that consumers recognized by one or another product (p.340).

Very important is the point of view on the evolution of sources of competitive development created by an American economist and professor at Columbia University (Stiglitz, 1999). In his work "Globalization and Its Discontents", he emphasized that knowledge should be recognized not only as public but also as a global good and this has the collective responsibility of the international community for the creation and dissemination of knowledge for the benefit of development( Stiglitz, 1999 ).

Contribution to the development of the conceptual foundations of the "knowledge economy" is reflected in many works of the world's scholars. In particular, the issue of developing a system of indicators and indices characterizing the information economy and knowledge became the subject of research by Alguliyev, \& Aliyev (2019). The authors carried out a comparative analysis of the system of various indicators in accordance with the formation and evaluation of the level of knowledge economy development. Their main focus was on the information component.

The trajectories of the knowledge economy in the countries CCA and MENA were studied by Asongu, \& Andrés (2019). In the critical assessment of the dynamic ways of the knowledge economy in Africa and the Middle East, the authors cited the study of countrywide disparities in knowledge-based economies. In particular, they studied the components of Africa and the Middle East, the knowledge economy index, and the knowledge index. The main conclusion drawn from those studies was that sub-Saharan Africa (SSA), the Middle East and North Africa (MENA) countries with a low level of knowledge-economy index dynamics were catching up with their counterparts, where this figure was higher.

Tremendous research work is devoted to the Myanmar economy (Sinha, 2018). In his research, the author came to the conclusion that under present conditions, the role of experimental skills and innovation activity was the basis of the knowledge-based economy. Research-based innovation and skills play a significant role in new contributions and consistent growth in all sectors of the economy. Thus, the author came to the conclusion that Myanmar was making great efforts to encourage citizens to research innovation in the creation of a country based on which knowledge had a primary role. The author also stated that the skills of employment among students and professionals made them professionally competent. That helped a county to form a knowledge-based economy (KBE). However, the author gave his recommendations on problems that arose in the country and assessed the position of the Government of Myanmar.

Scientists from Ukraine (Kinash, Andrusiv, Golovnia, \& Popadynets, 2019) argued that science and education are a reliable segment for the diffusion of innovations. The best practices of Ukrainian universities on the commercialization of innovative developments and technology transfer in the domestic and foreign markets are presented.

The study of the economy of Northern Cyprus and other countries is dedicated to the work of Savuşoğlu ( 2018). The aim of the study was to calculate the values of the knowledge economy 
index and knowledge index for Northern Cyprus and compare it with other countries. The study also aimed to measure the overall level of readiness of the economy of Northern Cyprus to the knowledge economy with the calculation of the index of the knowledge economy (KEI) and the country's index of knowledge (KI). The main methodology used to calculate these index values was the knowledge assessment method that was developed and used by the World Bank. The author noted that Northern Cyprus had the Knowledge Economy Index (KEI) less than Turkey and Southern Cyprus, but more than the average index of lower middle-income countries. It was concluded that the significance of the index of education and the ICT index of Northern Cyprus was higher than its competitors and the global average, but the index of economic stimulation and institutional regime and the index of innovation of the country was rather low.

The growing role of knowledge in the economy led to the emergence of an economy based on knowledge. A knowledge-based economy is an economy based on the production, distribution, application and use of knowledge (Mousavi, Moeinfar, \& Amouzesh, 2013). In a knowledge-based economy, public policy, in particular technology-related policies, industry and education, needs more attention. The role of economic firms, infrastructures and the creation of incentives for investment and education and training is significant. In this regard, public policy should aim at creating a context for cooperation between the state, industry and the university, so that this cooperation strengthens, improves and encourages new technologies in all sectors of the economy and various firms, and contributes to the development of information infrastructure.

The study of the impact of various indicators related to knowledge economy on the country's competitiveness in the European Union (EU) became the subject of a study by Dima, Begu, Vasilescu, \& Maassen ( 2018). Based on Pearson coefficients and panel data regression, the authors analyzed the Global Competitiveness Index (GCI) for research and development costs (in\% of gross domestic product (GDP)), percentage of people with higher education, lifelong learning, GDP per capita population and debt to equity. It was determined that the development of EU policies on learning opportunities throughout the life of the European workforce and focusing on research and development could significantly contribute to the competitiveness of the EU Member States.

The development of a knowledge economy in the Arab world was studied from the standpoint of theoretical and research approaches (Nour, 2015). The author analysed the indicators of the knowledge economy and indicators of knowledge used in the literature to study the existence and development of the knowledge economy in the Arab region. He decided that economics knowledge exists in the Arab region and coincides with a significant gap in knowledge in comparison with other regions of the world. Thus, for the Arab region, it is essential to strengthening the knowledge economy and indicators to achieve economic development.

Numerous studies are devoted to the pace of growth and the level of development of countries. The analysis of the Turkish economy (Demir, Genc, Alp, \& Yildirim, 2015) makes it possible to say that knowledge is one of the most critical indicators for achieving sustainable growth and development. Education is considered to be the main contribution to society, which is known as a "knowledge society."

Determinants of the knowledge economy (Ivanov, \& Tyshchenko, 2015) were studied by Ukrainian scientists. The methodical approach to the classification of regions of Ukraine depending on the level of development of the knowledge economy and the potential of public-private partnerships was proposed. It had been proved that public-private partnerships could become the institution of accelerated development in the direction of the knowledge economy through the division of the state (public sector) and the multiplier effect of business (private sector).

Researchers (Hope, \& Martelli, 2019) investigated the transition to a knowledge economy in the leading democracies of the world, which was backed by a revolution in information and communication technologies (ICTs). 
Rahmani, Najafi, and Karimi (2019), in their studies, have established that humanity has undergone three developmental revolutions they are agricultural, industrial, and economical. As for the latter, which is based on the knowledge of the Era, the application of knowledge is the most critical factor for production (economic revolution). It is assumed that knowledge is the driving force of industrial and economic progress to a greater extent than any other factor. And scientists (Ali, Musawir, \& Ali, 2018) agree with this opinion, having proposed an integrated model for studying the impact of knowledge management, knowledge sharing and capacity-building on the project's effectiveness in the context of project organizations.

However, despite the numerous scientific and research results of Ukrainian and foreign scientists regarding the development of the knowledge economy, and in particular the analysis of its constituent, controversial and extremely relevant for Ukraine, there remain problems related to the implementation of the knowledge economy by the territories, the growth of the role of intellectual capital and the need Innovative reforms in modern conditions.

\section{METHODOLOGY OF KNOWLEDGE ECONOMY AND MEASUREMENT INDICATORS}

The main components of the knowledge economy are high-quality and continuous education, economic incentives and institutional arrangements, and an effective innovation system, and information infrastructure.

The socio-economic development of Ukraine is characterized by a change in values and priorities of social development. Taking into account the ambiguity and unevenness of the economic, territorial development of Ukraine, the methodology of the knowledge measuring economy plays an important role in the process of analyzing educational, innovative or informational advantages.

The Knowledge Assessment methodology developed by the specialists of the World Bank Institute provides an analysis of countries' readiness to transition to a knowledge economy. Indicators are the Knowledge Economy Index (The Knowledge Economy Index - KEI) and the
Knowledge Index (The Knowledge Index - KI). These indicators are calculated for each country or group of countries and are used to determine the position of the regions and their readiness for the development of the knowledge economy (Chen, 2005).

Analysing global trends in economic development, it can be argued that the leaders in terms of the Knowledge Economy Index are Sweden, Finland, Denmark, and the Netherlands, where the indicated indicator is at least 9.00. Regarding the western neighbouring countries of Ukraine, in the last decade (from 2012 to the present), they are significantly lower in this component (more than 2.00 points in Slovakia, Poland, Hungary, more than 1.00 in Romania) (Index, 2018).

Despite the problems in the socio-political sphere of Ukraine, the index of knowledge economy in recent years has been characterized by a positive dynamism, mainly due to the growth of the education index and the index of development of modern information infrastructure, which confirms the path to modernization of the educational and scientific sphere, and as well as information technology.

Nevertheless, the negative phenomenon is the decline of the economic index and institutional regime, as well as the index of innovations. Such processes reflect a slightly conservative attitude of the state towards the stimulation of scientific and technological progress and the strengthening of innovation and investment activity. They make it necessary for the state to take measures for the transition of the Ukrainian economy to the efficient use of intellectual resources through the development and implementation of a long-term strategy for the accumulation and increase of human capital.

\section{ANALYSIS OF CHANGES IN THE INDEX OF KNOWLEDGE ECONOMY AND KNOWLEDGE INDEX FOR THE PERIOD 2015-2017}

For a detailed assessment of the trends of the introduction of the knowledge economy in Ukraine, we use the data presented in Annex A.1.

These regions as are considered industrial centers of Ukraine, which concentrate on high- 
tech industrial production (more than $2 / 3$ of high technologies).

The leading positions in the dynamics of growth of the knowledge economy index were occupied by Kyiv, Zaporizhzhia and Lviv regions. In recent years, enterprises in these areas have, to a higher degree, redirected their development strategies to the innovation spectrum, drawing on the results of Ukrainian research and development.

Among the so-called "persecutors" are Poltava, Cherkasy, Vinnytsia and Sumy regions, which are mainly oriented to the agro-industrial complex and the service sector, and have all the prerequisites for activating the innovation potential in these types of activities.

Within the limits of the slight fluctuations of the index of knowledge economy were Kherson, Rivne, Chernigiv, Transcarpathian, and Zhytomyr regions. Usually in their economic system, they use traditional types of resources (energy, fuel, raw materials), which weakens the development and productivity of public knowledge. The key areas are the branches of the processing industry. Little funding for the intellectual sphere, including the development of strategic plans for enterprises, is noticeable.

The list of "outsiders" or "anti-leaders" is headed by Kirovohrad, Ternopil, IvanoFrankivsk regions. The low level of wages, the massive outflow of personnel, and the lack of specialists of the relevant qualifications employed in the field of education and science create the unsatisfactory status of the innovation environment.

Among the areas that require special attention, we will mention Volyn, Chernivtsi, Khmelnytsky. They are identified with a "risk group" because they balance without significant changes in the growth of the index of economic knowledge. The institutional regime and low quality of human resources are considered as problematic components, which along with undeveloped, even partially missing information component, restrain alternative directions to the innovative vector of Ukraine's development.

Similar trends in changes in individual components of the knowledge economy index were observed over 2015-2017 (see Annex A.1).
Often, according to the socio-economic identity of Ukraine, Ukraine is compared with Poland, although such a comparison is not entirely correct, because in spite of the vast territory and the prevalence of the population, the domestic economy at the level of GDP almost five times, falls behind the economy of a western neighbor country.

The main competitive advantages of the Polish economy are openness and transparency of the economy (in the ranking of economic globalization, Poland ranks 39th out of 191 countries; Ukraine is 79th); freedom of business; maximum deregulation; and high human potential (Poland's Human Development Index for 2017 - 0,865 - 33rd in the world).

The multivariate financing (state, local budget, private business sector) forms the budget of Poland for science in the amount of 1,65 million euros ( $1 \%$ of GDP, according to 2017). In Ukraine, this figure is about 200 million euros ( $0,6 \%$ of GDP) (Senenko, 2017). To get closer to Poland's economic level, Ukraine needs almost 50 years in the presence of a favourable economic environment. If the national economy continues to grow at a rate similar to that in 2017, Ukraine will achieve its level of economic development only in 49 years. If growth is as in 2018, then in 36 years (From socialism, 2018).

The question arises: what is needed to be changed in order to reach a qualitatively new level of knowledge economy development?

\section{THE MAIN WAYS OF INTRODUCING THE KNOWLEDGE ECONOMY IN UKRAINE AND ITS STEP-BY-STEP CHARACTERISTICS}

The main steps and paths along the key fundamental blocks are as follows.

1. Economic regime. First of all, it is necessary to increase the prestige and material incentives of employees of the "knowledge sector," as well as to ensure the possibility of free access to knowledge, controlling, first of all, their commercial use. It is also advisable to:

a) deregulate small and medium-sized businesses, by improving the legal and regulatory framework;

b) diversify services by the creation of organizational conditions for the 
development of telecommunication, financial, consulting activities;

c) provide state insurance of innovative risks of high-tech enterprises;

d) strengthen the state mechanism of protection of intellectual property rights through the legislative field, etc.

2. ICT Infrastructure. For Ukraine, methods and ways of dissemination, and processing of information become an "artery" of the economic knowledge functioning, but at the pace of implementation and use of modern ICT technologies, the Ukraine is far behind, lagging behind the leading countries, for at least 10-15 years (Androschuk, 2017). Inert management sector does not contribute to the effective implementation of existing technologies. Appropriate in this situation will be an entirely new administrative reform of the consolidation of the ICT management system, harmonized with international standards of forecasting and technology assessment.

3. Innovations. Ukraine in the Global Innovation Rating of Countries developed by the Bloomberg Agency in 2017, took 50th place from 127 countries, strengthening its positions by six points compared to 2016. Also, Ukraine, together with Mongolia and Vietnam, fell into the section "Leaders of Innovation" by regions among countries with a lower income than the average income level. Within the framework of the GII Ukraine is considered in the segment of "prosperous effective innovators" (Androschuk, 2017). The strongest indicators of Ukraine in terms of innovation are: the coverage of the population with higher education (the fourth rating position in the world), patent activity (27 rating positions), and technological capabilities of industry (34 rating positions) (UKRAINE 2030, 2018). Such results demonstrate an increase in the efficiency of innovation activities in the country.

In order to increase and strengthen the innovative potential of Ukraine, it is necessary to identify existing technological advances and identify a peculiar catalyst for progressive changes. One of these catalysts could be investment in the development of IT industry.

4. Education. The Ukrainian system of education needs reforms and modernization: the forms and methods of teaching a decade ago have lost their effectiveness; the theory is not backed by practice; practical skills and abilities do not satisfy employers; institutions of higher education are isolated from the realities of the present, have little contact with business and are "hostage to the state order." Ukrainian higher education institutions are not competitive in the foreign market. According to the World University Rankings, only six universities are included in this list (the best Kyiv National University is on the 421 place) (Knowledge, 2011).

The analysis of the index of knowledge on the educational component proves that the potential of higher education in Ukraine corresponds quantitatively to the potential of the higher education system of the leading European countries. But qualitatively, it is not able to significantly influence the country's economic growth on the basis of the intellectual resource due to the lack of sufficient level of quality of received competences, because, in the modern innovative economy, knowledge should be oriented on the economic result, and education - on the demands of the labor market (Zelinska, 2013).

5. Science. Ukraine has a strong, highly developed research potential capable of solving the most current innovative challenges. The number of scientists in Ukraine is about $0.54 \%$ of the number of the economically active population (the number of researchers is $0,41 \%$ ). In 2018, R-\& D expenditure in Ukraine was 0,22 $\%$ of GDP, while in developed countries it reached $3-4 \%$. Such a low level of financing for the scientific and innovation sphere not only reduces the intensity and effectiveness of innovation activities in the state but also restricts its competitive position in the struggle for markets for high-tech and high-tech products. Rising $\mathrm{R} \& \mathrm{D}$ expenditures in most countries of the world testify to the fact that science is seen as a significant factor in economic growth and social development. Therefore, it is clear that encouraging research and development by research institutions and private business, strengthening the links between research institutes, universities with the corporate sector for the transfer of 
technologies and their commercialization is an urgent task today.

We believe that all of the above steps and actions can be implemented through the formation of a new outlook and transformation of consciousness (first of all civil servants) and the emergence of an innovative culture at the level of the individual as well as at the level of the population as a whole. An equally important prerequisite for the introduction of the knowledge economy is the creation of knowledge management institutes that structure the institutes of knowledge creation (knowledge generation, formalization), their distribution (diffusion, knowledge sharing) and use (institutions of coordination, control and risk assessment of knowledge application) (Toffler, 2008). In this context, one of the modern progressive forms of knowledge economy development is the mechanism of interaction between state and local authorities, educational and scientific institutions, and private businesses based on public-private partnerships. Given the unevenness and significant gap in the economic development of the territories, this process is a long-term one but is essential for sustainable socio-economic growth.

\section{CONCLUSIONS}

Global development of the world testifies to the urgency of the introduction and application of the knowledge economy concept, - which today, quite naturally, is considered as the basis of the economic growth policy. It demonstrates the role and significance of human intelligence in social processes in economically developed countries is considered as a mandatory state instrument of the social and economical provision of sustainable development of countries.

Consequently, the new economic model of Ukraine's development should be based on knowledge, high morals, genuine solidarity of citizens and corporate culture.

Taking into account the slowdown in the development of the knowledge economy in Ukraine, research into the main factors influencing the economic growth in the current conditions and the impact of the new economy on the indicators of population development should be continued.

\section{REFERENCES}

Alguliyev, R. M., \& Aliyev, A. G. (2019). The development of indicators and indices system characterizing information and knowledge economy. Paper presented at the 11th IEEE International Conference on Application of Information and Communication Technologies, AICT 2017 Proceedings, Retrieved from https://doi.org/10.1109/ICAICT.2017.868726 3

Ali, I., Musawir, A. U., \& Ali, M. (2018). Impact of knowledge sharing and absorptive capacity on project performance: The moderating role of social processes. Journal of Knowledge Management, 22(2), 453-477. Retrieved from doi:10.1108/JKM-10-20160449

Androschuk, G.O. (2017). Assessment of the development of national innovation systems. Materials of the XIIII International Scientific and Practical Conference. Retrieved from https://www.google.com.ua/url?sa=t\&rct=j\& $\mathrm{q}=\& \mathrm{esrc}=\mathrm{s} \&$ source $=$ web\&cd $=1 \& \mathrm{cad}=\mathrm{rja} \& u a c$ $\mathrm{t}=8$ \&ved=2ahUKEwidjP3PpbjhAhXBKQKHd6 qAOsQFjAAegQIABAC\&url=https\%3A\%2F\%2F stepscenter.org.ua\%2Farchives\%2Fodessa201 7.pdf\&usg=AOvVaw1IXWA3MgXaoUE5IE96 MwsF

Asongu, S. A., \& Andrés, A. R. (2019). Trajectories of knowledge economy in SSA and MENA countries. Technology in Society, https://doi.org/10.1016/j.techsoc.2019.03.00 2

Çavuşoğlu, B. (2018) Knowledge-baseded economy: Where does North Cyprus stand? Paper presented at the Proceedings of the European Conference on Knowledge Management, ECKM , pp. 132-140.

Chen, D. (2005). The Knowledge Economy, KAM Methodology and World Bank Operations.

Demir, O., Genc, E. G., Alp, E. A., \& Yildirim, F. (2015). A new knowledge society index: Global tendencies and an analysis of turkey. Kuram Ve Uygulamada Egitim Bilimleri, 
15(2), pp. 325-335.

https://doi.org/10.12738/estp.2015.2.2356

Dima, A. M., Begu, L., Vasilescu, M. D., \& Maassen, M. A. (2018). The relationship between the knowledge economy and global competitiveness in the European Union. Sustainability (Switzerland), 10(6). Retrieved from https://doi.org/10.3390/su10061706

From socialism to a prosperous country: 16 charts about the economy Police (2018) from https:

//businessviews.com.ua/en/economy/id/eko nomika-polschi-1930/

Hope, D., \& Martelli, A. (2019). The transition to the knowledge economy, labor market institutions, and income inequality in advanced democracies. World Politics, 71(2), 236-288. Retrieved from doi:10.1017/S0043887118000333

Index of knowledge economy, calculated according to the World Bank methodology (2018) Retrieved from https: //gtmarket.ru/ratings/ knowledge-economyindex/knowledge-economy-index-info

Ivanov, Y., \& Tyshchenko, V. (2015). Publicprivate partnership potential in knowledge economy: Regional aspect. Economic Annals-XXI, 3-4(1), pp.28-31.

Kinash, I., Andrusiv, U., Golovnia, O \& Popadynets, I. (2019). Aspects of the formation and development of innovation infrastructure in Ukraine. Management Science Letters, 9(13), 2403-2414. Retrieved from https://doi.org/10.5267/j.msl.2019.7.015

Knowledge economy (2011): what should be the country's development strategy. And why Ukraine is still lagging behind? Retrieved from http://forbes.net.ua/ru/opinions/1413550ekonomika-znan-yakoyu-mae-butistrategiya-rozvitku-krayini

Mousavi, Z., Moeinfar, Z., \& Amouzesh, N. (2013). The role of intellectual capital in knowledge-based economy. Life Science Journal, 10(SUPPL.6), pp. 56-60.
Nour, S. S. O. M. (2015). Overview of knowledge economy in the arab region. Journal of the Knowledge Economy, 6(4), 870-904. Retrieved from https://doi.org/10.1007/s13132-013-0153-8.

Rahmani, A., Najafi, S. M. B., \& Karimi, M. S. (2019). An introduction to the criteria for selecting leading knowledge. Iranian Journal of Information Processing Management, 34(2), 487-516. Retrieved from http://siteresources. worldbank.org/KFDLP/Resources/KAM_Pape r WP. Pdf

Sakayya ,T. (1999). The Value Created by Knowledge, or The History of the Future. A New Post-Industrial Wave in the West. Anthology (pp. 340-640) Moscow, Russia: Academia.

Senenko, A. (2017) How does science work in Poland? Retrieved from https://site.ua/anton.senenko/10838/.

Sinha, G. R. (2018). Innovation and research skill for knowledge-based economy of Myanmar: Current status and recommendation. Journal of Science and Technology Policy Management, Retrieved from https://doi.org/10.1108/JSTPM-12-20170078

State Committee of Statistics of Ukraine, (20122017), Regions of Ukraine in 2017, 2 volumes, Kyiv. Retrieved from www.ukrstat.gov.ua.

Stiglitz, J. World Development Report, (1998/99). Knowledge for Development. Retrieved April 20-21, 1999.

Toffler, E. (2008). Revolutionary wealth: how it will be created and how it will change our lives. Moscow, Russia: AST.

UKRAINE 2030: Doctrine of balanced development (2018). Retrieved from http: //econom.chnu.edu.ua/wpcontent/uploads/2018/03/E-Book-Doctrine2030.pdf

Zelinska, H.O. (2013). Educational Management and Globalization Challenges: Regional Aspect. Modern problems of social and economic development. pp.75-77. 


\section{Annex A.1}

Indicators of the development of the knowledge economy in Ukraine during 2015-2017

\begin{tabular}{|c|c|c|c|c|c|c|c|c|c|c|c|c|c|c|c|}
\hline \multirow[t]{2}{*}{ Regions } & \multicolumn{3}{|c|}{ KEI } & \multicolumn{3}{|c|}{$\begin{array}{l}\text { Institutional } \\
\text { regime }\end{array}$} & \multicolumn{3}{|c|}{$\begin{array}{l}\text { Innovation } \\
\text { system }\end{array}$} & \multicolumn{3}{|c|}{$\begin{array}{l}\text { Education and } \\
\text { quality of } \\
\text { human } \\
\text { resources }\end{array}$} & \multicolumn{3}{|c|}{$\begin{array}{l}\text { Information } \\
\text { infrastructure }\end{array}$} \\
\hline & 2015 & 2016 & 2017 & 2015 & 2016 & 2017 & 2015 & 2016 & 2017 & 2015 & 2016 & 2017 & 2015 & 2016 & 2017 \\
\hline Vinnytsia & 2,95 & 2,97 & 2,96 & 3,39 & 3,46 & 3,44 & 2,57 & 2,54 & 2,54 & 3,26 & 3,26 & 3,24 & 2,59 & 2,60 & 2,60 \\
\hline Volyn region & 2,08 & 2,06 & 2,05 & 1,74 & 1,72 & 1,70 & 2,39 & 2,38 & 2,36 & 2,15 & 2,14 & 2,12 & 2,06 & 2,01 & 2,02 \\
\hline Dniprovska & 5,31 & 5,36 & 5,38 & 4,63 & 4,68 & 4,70 & 5,39 & 5,41 & 5,44 & 7,34 & 7,41 & 7,40 & 3,90 & 3,95 & 3,99 \\
\hline Zhytomyr & 2,68 & 2,66 & 2,63 & 2,63 & 2,58 & 2,59 & 2,46 & 2,43 & 2,38 & 2,95 & 2,95 & 2,91 & 2,68 & 2,66 & 2,64 \\
\hline $\begin{array}{l}\text { Transcarpath } \\
\text { ian }\end{array}$ & 2,59 & 2,59 & 2,59 & 2,06 & 2,08 & 2,09 & 2,63 & 2,62 & 2,60 & 3,48 & 3,49 & 3,50 & 2,18 & 2,17 & 2,15 \\
\hline Zaporizhia & 3,64 & 3,71 & 3,71 & 0,96 & & 1,02 & 4,04 & 4,08 & 4,07 & 6,30 & 6,44 & 6,43 & 3,28 & 3,32 & 3,30 \\
\hline $\begin{array}{l}\text { Ivano- } \\
\text { Frankivsk }\end{array}$ & 1,88 & 1,95 & 1,97 & 1,80 & 1,92 & 1,95 & 2,55 & 2,62 & 2,66 & 1,18 & 1,21 & 1,22 & 1,99 & 2,03 & 2,04 \\
\hline Kyiv & 3,33 & 3,42 & 3,46 & 3,59 & 3,66 & 3,69 & 3,16 & 3,33 & 3,39 & 3,65 & 3,70 & 3,72 & 2,93 & 2,99 & 3,02 \\
\hline Kirovo & 1,53 & 1,53 & 1,52 & $-0,12$ & $-0,05$ & $-0,04$ & 2,59 & 2,58 & 2,56 & 1,20 & 1,19 & 1,17 & 2,43 & 2,38 & 2,39 \\
\hline Lviv & 3,64 & 3,83 & 3,87 & 3,77 & 3,91 & 3,92 & 4,03 & 4,31 & 4,33 & 3,61 & 3,84 & 3,88 & 3,16 & 3,29 & 3,35 \\
\hline Mykolayiv & 3,46 & 3,45 & 3,43 & 2,39 & 2,39 & 2,37 & 3,82 & 3,8 & 3,79 & 4,66 & 4,64 & 4,64 & 2,97 & 2,91 & 2,92 \\
\hline Odesa & 4,90 & 4,97 & 5,00 & 4,08 & 4,10 & 4,12 & 3,46 & 3,56 & 3,61 & 3,21 & 3,29 & 3,31 & 8,87 & 8,92 & 8,95 \\
\hline Poltava & 2,69 & 2,71 & 2,71 & 2,47 & 2,49 & 2,50 & 2,65 & 2,65 & 2,66 & 3,13 & 3,14 & 3,13 & 2,53 & 2,55 & 2,56 \\
\hline Rivne & 2,57 & 2,56 & 2,53 & 1,96 & 1,96 & 1,96 & 2,38 & 2,37 & 2,34 & 4,10 & 4,05 & 4,02 & 1,85 & 1,84 & 1,80 \\
\hline Sumy & 3,15 & 3,10 & 3,06 & 1,98 & 1,95 & 1,90 & 3,49 & 3,46 & 3,41 & 4,33 & 4,31 & 4,28 & 2,79 & 2,68 & 2,66 \\
\hline Ternopil & 1,72 & 1,73 & 1,74 & 1,80 & 1,81 & 1,82 & 2,41 & 2,42 & 2,42 & 0,42 & 0,41 & 0,43 & 2,26 & 2,28 & 2,29 \\
\hline Kharkiv & 6,35 & 6,38 & 6,39 & 5,44 & 5,49 & 5,50 & 9,97 & 9,90 & 9,98 & 7,09 & 7,12 & 7,13 & 2,89 & 2,93 & 2,95 \\
\hline Kherson & 2,50 & 2,52 & 2,52 & 2,02 & 2,04 & 2,03 & 2,83 & 2,85 & 2,86 & 2,88 & 2,89 & 2,87 & 2,28 & 2,30 & 2,31 \\
\hline Khmelnytsky & 2,34 & 2,31 & 2,30 & 2,43 & 2,39 & 2,39 & 2,37 & 2,34 & 2,33 & 2,34 & 2,32 & 2,30 & 2,21 & 2,18 & 2,17 \\
\hline Cherkasy & 2,78 & 2,76 & 2,77 & 2,33 & 2,31 & 2,32 & 2,70 & 2,70 & 2,71 & 3,84 & 3,80 & 3,81 & 2,23 & 2,23 & 2,24 \\
\hline Chernivtsi & 2,23 & 2,25 & 2,27 & 1,37 & 1,39 & 1,41 & 2,85 & 2,87 & 2,89 & 2,71 & 2,74 & 2,76 & 1,98 & 1,98 & 1,99 \\
\hline Chernihiv & 2,59 & 2,56 & 2,54 & 2,06 & 2,05 & 2,04 & 2,62 & 2,59 & 2,57 & 2,72 & 2,68 & 2,66 & 2,94 & 2,93 & 2,90 \\
\hline
\end{tabular}

Source: Built by the authors on the basis of State 


\section{ABOUT THE AUTHORS}

Halyna Zelinska, e-mail: zelinska_haluna@i.ua

Dr, Halyna Zelinska is a professor of the Department of Applied Economics of the Ivano-Frankivsk National Technical University of Oil and Gas, Ukraine. Scope of his scientific interests: regional educational management, regional labor market, human resources, knowledge economy. She has published more than 100 scientific papers. Works in professional journals in Ukraine and in international journals, including in the International Journal of Engineering \& Technology (Scopus), etc.

Uliana Andrusiv is a Candidate of Economic Sciences, Ulyana Andrusiv is Associate Professor of the Department of Economics and Management of the Ivano-Frankivsk National Technical University of Oil and Gas, Ukraine. Sphere of scientific interests: competitiveness, innovative activity, tourism. Has published more than 75 scientific works. Works in professional journals in Ukraine and in international journals, including in the Regional Scientific Research (Scopus) and Scientific Bulletin Polissia (Web of Science), etc.

Dr, Liliia Simkiv is an assistant professor of the Department of Theory of Economics and Management of the Ivano-Frankivsk National Technical University of Oil and Gas, Ukraine. Scope of scientific interests: development and implementation of regional economic policy analysis and evaluation of regional development disparities, studying the characteristics of innovation activity in the regions. She has published more than 100 scientific papers in professional journals in Ukraine and abroad. 